\author{
Benita HRYĆ, GRAŻYNA ZGÓRKA \\ Katedra i Zakład Farmakognozji z Pracownia Roślin Leczniczych \\ Uniwersytet Medyczny $w$ Lublinie \\ ul. Chodźki 1, 20-093 Lublin \\ e-mail: benita.hryc@gmail.com \\ gzgorka@pharmacognosy.org
}

\title{
TARCZYCE - ROŚLINNE ADAPTOGENY Z RÓŻNYCH KONTYNENTÓW
}

\section{WSTEP}

Pojęcie adaptogenu zostało po raz pierwszy użyte przez Mikołaja Lazarewa w 1947 r. (PANOSSIAN i współaut. 1999) i miało oznaczać substancje chemiczne pochodzenia organicznego bądź nieorganicznego, które zwiększaja nieswoista oporność (rezystencję) organizmu na stres. Następnie definicję rozszerzono i opisano trzy podstawowe kryteria, charakteryzujace substancje o właściwościach adaptogennych. Po pierwsze, adaptogen powinien zwiększać oporność organizmu wobec szerokiego spektrum szkodliwych czynników fizycznych, chemicznych i biologicznych, które ogólnie nazywane sa stresorami. Po drugie, substancja taka powinna charakteryzować się normalizującym wpływem na organizm w odpowiedzi na działanie stresorów. Po trzecie, adaptogen, obok posiadania szerokiego zakresu aktywności biologicznej, nie powinien wykazywać efektów toksycznych, a więc charakteryzować się wysokim wskaźnikiem terapeutycznym. PANOSSIAN i współaut. (1999) opisali mechanizm działania adaptogenów w odniesieniu do dwóch systemów czynników endogennych: włacczenia (ang. switch on), który mobilizuje organizm do walki ze stresem, oraz wyłączenia (ang. switch off), który ma za zadanie ochronę komórek, tkanek i narzadów przed nadmierna reakcja na stres. Szkodliwy wpływ stresorów na organizm jest wynikiem zakłócenia równowagi pomiędzy tymi dwoma systemami, adaptogeny natomiast maja za zadanie jej przywrócenie. W procesie mobilizacji organizmu w sytuacjach narażenia na czynniki stresogenne biora m.in. udział katecholaminy (adrenalina, noradrenalina), uwalniane w procesie aktywacji układu współczulnego. Skutkiem ich działania jest przyspieszenie akcji serca, wzrost ciśnienia i zwiększenie przepływu krwi przez mięśnie szkieletowe, a także, pośrednio, zwiększenie poziomu glukozy we krwi. Pobudzone zostaja także procesy kataboliczne. $Z$ kolei podczas ograniczania nadmiernej reakcji organizmu na stres, mobilizowany jest układ immunologiczny i ośrodkowy układ nerwowy (OUN). Aktywacja osi podwzgórze-przysadka-nadnercza doprowadza do zwiększenia uwalniania hormonu adrenokortykotropowego (ACTH), który $z$ kolei pobudza sekrecje kortyzolu (glikokortykosteroidu) w korze nadnerczy. Kortyzol jest więc głównym czynnikiem, wpływającym na ograniczenie niekorzystnych skutków rozwiniętej reakcji organizmu na działanie stresorów (KONTUREK 2007). Substancje adaptogenne charakteryzują się silnym działaniem antyoksydacyjnym i przeciwwolnorodnikowym. Ponadto, usprawniaja funkcje fizjologiczne różnych narządów, w tym mózgu, co wyraża się m.in. w poprawie zdolności koncentracji i zapamiętywania. Działaja uspokajająco, poprawiają nastrój i przeciwdziałaja dysfunkcjom seksualnym, związanym $z$ deficytem hormonów płciowych. Wykazuja także działanie cytoprotekcyjnie, m.in. chroniąc komórki czynnościowe watroby (hepatocyty) przed uszkadzajacym wpływem reaktywnych form tlenu (RFT). Adaptogeny hamuja procesy miażdżycowe w naczyniach krwionośnych, obniżajac poziom cholesterolu w osoczu, jak również ( $z$ wyjątkiem ostrej fazy reakcji na stres) wpływaja normalizujacco na poziom 
glukozy we krwi, wykazując aktywność przeciwcukrzycowa (OBIDOSKA i SADOwSKA 2004).

Jednym $z$ najbardziej znanych roślinnych adaptogenów, wywodzących się $z$ Tradycyjnej Medycyny Chińskiej (TCM), jest korzeń żeń-szenia (WU 2005), który traktowany jest obecnie jako adaptogenna substancja referencyjna. Aktualne dane $z$ badań klinicznych wskazuja, iż saponinowe składniki korzenia żeń-szenia (ginsenozydy) są odpowiedzialne za szereg korzystnych efektów terapeutycznych w organizmie ludzkim, w tym działanie przeciwcukrzycowe (zwiazane m.in. ze zwiększona sekrecja insuliny $\mathrm{w}$ komórkach beta trzustki) i ochronne na komórki wątroby, czy regulujace metabolizm $\mathrm{w}$ hepatocytach. Wpływaja także na sfere psychomotoryczna organizmu, poprawiając zdolności poznawcze umysłu, koncentrację i pamięć, a także zwiększają ogólną wydolność psychofizyczną (w tym seksualna). Oprócz tego, korzeń żeń-szenia charakteryzuje się aktywnością neuro- i kardioprotekcyjną. Substancje w nim zawarte nie maja istotnych działań niepożądanych, a jego stosowanie jest bezpieczne (LEE i SoN 2011). Inne popularne roślinne adaptogeny to: korzeń różeńca górskiego i eleuterokoka kolczastego oraz owoc cytryńca chińskiego, których składniki aktywne pełnia $\mathrm{m}$.in. istotna role $\mathrm{w}$ terapii zespołu chronicznego zmęczenia (ang. chronic fatigue syndrome, CFD), poprawiajac wydolność układu krażenia, a także OUN, w tym funkcje kognitywne i procesy kojarzenia (PANOSSIAN i WIKMAN 2009). W ostatnich dwóch dekadach, do grupy gatunków roślin o właściwościach adaptogennych dołączyła tarczyca bajkalska (Scutellaria baicalensis Georgi., Lamiaceae) oraz taksony pokrewne $z$ tego rodzaju, zawierajace szereg bioaktywnych zwiazków polifenolowych. Celem niniejszego artykułu jest przedstawienie potencjału leczniczego trzech spośród nich: tarczycy bajkalskiej (S. baicalensis Georgi.), tarczycy brodatej (S. barbata D. Don.) i tarczycy bocznokwiatowej (S. lateriflora L.), których chemizm oraz właściwości terapeutyczne zostały najlepiej poznane, a ich przetwory (w tym standaryzowane ekstrakty) wykorzystuje się już $\mathrm{w}$ pewnym stopniu w lecznictwie.

Rodzaj Scutellaria L. (tarczyca) obejmuje ok. 460 gatunków roślin $z$ różnych kontynentów (THE PLANT LIST 2013), które wystepuja w rejonach górskich strefy zwrotnikowej i strefie klimatu umiarkowanego. Sa to najczęściej byliny, rzadziej rośliny jednoroczne, dwuletnie czy półkrzewy. $\mathrm{Na}-$ zwa Scutellaria wywodzi się od łacińskiego słowa scutella, które oznacza „miseczkę, tarczkę" i odnosi sie do charakterystycznego wytworu okrywy kielicha, który ma kształt niewielkiej tarczy. Kwiaty tarczyc maja za- barwienie od fioletowego, poprzez różne odcienie niebieskiego, aż do białego, a nawet żółtego i charakteryzuje je dwuwargowa budowa kielicha i korony, typowa dla rodziny Lamiaceae. Kielich jest spłaszczony grzbietobrzusznie, a wargi całobrzegie. Warga górna cechuje się obecnością opisanej powyżej charakterystycznej tarczki. Owocem tarczyc sa rozłupki, nagie lub owłosione, $\mathrm{z}$ charakterystycznym brodawkowaniem (PAwEOWSKI 1967, SZAFER i współaut. 1988, RUTKOWSKI 1998).

\section{SKŁADNIKI AKTYWNE TARCZYC}

Głównymi składnikami biologicznie czynnymi, zidentyfikowanymi w rodzaju Scutellaria L., sa flawony i dihydroflawony (flawanony), reprezentujace szersza klasę flawonoidów (Ryc. 1). W grupie związków bezcukrowych (aglikonowych), których pochodne glikozydowe dominują zarówno w częściach podziemnych, jak i nadziemnych tarczyc wyróżnia się: bajkaleinę, wogoninę. skutelareinę, oroksylinę A, chryzynę czy apigeninę. Przeprowadzone liczne badania biologiczne wykazały, że właśnie te składniki polifenolowe $\mathrm{w}$ głównej mierze odpowiadaja za aktywność farmakologiczną tych taksonów (SHANG i współaut. 2010).
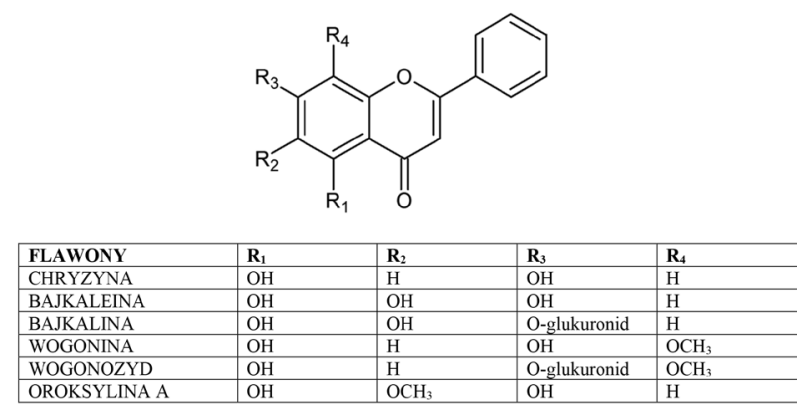

Ryc. 1. Główne związki flawonowe zidentyfikowane w korzeniach tarczyc (SHANG i współaut. 2010).

Oprócz flawonów, w omawianych gatunkach tarczyc odnotowano obecność biologicznie aktywnych składników polifenolowych $z$ grupy fenyloetanoidów oraz metabolitów wtórnych pochodnych izoprenu, reprezentowanych przez zwiazki diterpenowe i alkaloidy pochodne neo-klerodanu (Tabela 1).

\section{TARCZYCA BAJKALSKA}

Teren rodzimego wystepowania tarczycy bajkalskiej obejmuje środkowa i wschodnia Azję, zwłaszcza wschodnią Syberię, północne Chiny, Koreę i Japonię. Możemy ją również znaleźć w rejonie Jeziora Bajkał, od które- 
Tabela 1. Biologicznie aktywne składniki i ich występowanie w omawianych gatunkach tarczyc (SHANG i współaut. 2010).

\begin{tabular}{|c|c|c|c|}
\hline Składnik & S. baicalensis & S. barbata & S. lateriflora \\
\hline \multicolumn{4}{|c|}{ Flawony } \\
\hline apigenina & - & + & - \\
\hline chryzyna & + & - & - \\
\hline bajkalina & + & + & + \\
\hline bajkaleina & + & + & + \\
\hline norwogonina & + & - & - \\
\hline oroksylina A & + & - & - \\
\hline wogonina & + & + & + \\
\hline wogonozyd & + & - & - \\
\hline \multicolumn{4}{|c|}{ Fenyloetanoidy } \\
\hline akteozyd & + & - & - \\
\hline martynozyd & + & - & - \\
\hline \multicolumn{4}{|c|}{ Diterpeny } \\
\hline skutellony A-H & - & + & - \\
\hline barbatyny A-C & - & + & - \\
\hline skutelateryny A-C & - & - & + \\
\hline skutebajkalina & + & - & - \\
\hline \multicolumn{4}{|c|}{ Alkaloidy diterpenowe pochodne neo-klerodanu } \\
\hline skutebarbatyny A-G & - & + & - \\
\hline
\end{tabular}

go wywodzi się zreszta nazwa gatunku. Tarczyca bajkalska preferuje rejony stepowe i podgórskie o dużym nasłonecznieniu. Prosta, prawie naga łodyga tego gatunku osiaga do $60 \mathrm{~cm}$ wysokości. Liście, długości od 1 do $3 \mathrm{~cm}$, o kształcie lancetowatym lub jajowatym sa tępo zakończone i siedzace. Niebiesko-fioletowe lub fioletowe kwiaty zebrane sa w jednostronne kłosy (Ryc. 2A). W strefie klimatu środkowoeuropejskiego roślina kwitnie od czerwca do października (BowN 1999). Korzeń tarczycy bajkalskiej (Scutellariae baicalensis radix) jest od ponad 2.000 lat $z$ powodzeniem stosowany $w$ Tradycyjnej Medycynie Chińskiej, gdzie znany jest pod nazwa "Huang-qin”, co oznacza „złote zioło". Zapiski pochodzące $z$ ok. 200-250 r. mówia, że odwary $z$ korzenia stosowano w leczenia przeziębień oraz schorzeniach płuc i wątroby. W źródłowych dokumentach z XVI w., dotyczacych TCM, podaje się również, że korzeń wykorzystywano w leczeniu biegunek, w tym krwotocznych (dyzenterii), stanów zapalnych i infekcji układu oddechowego, nadciśnienia tętniczego czy bezsenności (ZHAO i współaut. 2016). Zgodnie $z$ wytycznymi TCM, korzeń tarczycy bajkalskiej powinien być zbierany wiosna lub jesienia, wysuszony na słońcu i pokrojony w plastry. Następnie, w zależności od rodzaju schorzenia, może być stosowany $\mathrm{w}$ formie nieprzetworzonej jako proszek lub (po upieczeniu) podany w winie albo w postaci odwaru. Współczesne zastosowania medyczne Huang-qin sa szerokie i uwzględniaja łączenie go $z$ innymi substancjami pochodzenia roślinnego. Lek ten najczęściej podaje się w goracczce i dreszczach, kaszlu, żółtaczce, biegunce, trudnym i bolesnym oddawaniu moczu, ropnych infekcjach skóry, różnego rodzaju krwotokach (krwawienie $z$ nosa, krwiomocz, wymioty $z$ krwia), a nawet $\mathrm{w}$ celu przeciwdziałania przedwczesnemu porodowi (TANG i współaut. 2008, Wu 2005). Medycyna europejska, opierając się na wynikach badań przedklinicznych i klinicznych, potwierdza szereg właściwości leczniczych (zwłaszcza działanie przeciwzapalne i przeciwdrobnoustrojowe) wyciagów $z$ tarczycy bajkalskiej, wykorzystywanych w TCM. Jednak, zwraca przede wszystkim uwage na walory adaptogenne tego gatunku, związane $z$ wszechstronna aktywnościa antybiodegeneracyjna. Jednym $z$ jej elementów jest działanie neuroprotekcyjne, udokumentowane $\mathrm{w}$ badaniach in vivo. Działanie ochronne w stosunku do komórek mózgu stwierdzono dla zespołu flawonów izolowanych z ziela tarczycy bajkalskiej. Przykładowo, w przebiegu niedokrwienia mózgu i następczej reperfuzji, skutkujacych uszkodzeniem struktur neuronalnych, składniki te ograniczały obszar objęty zawałem, 

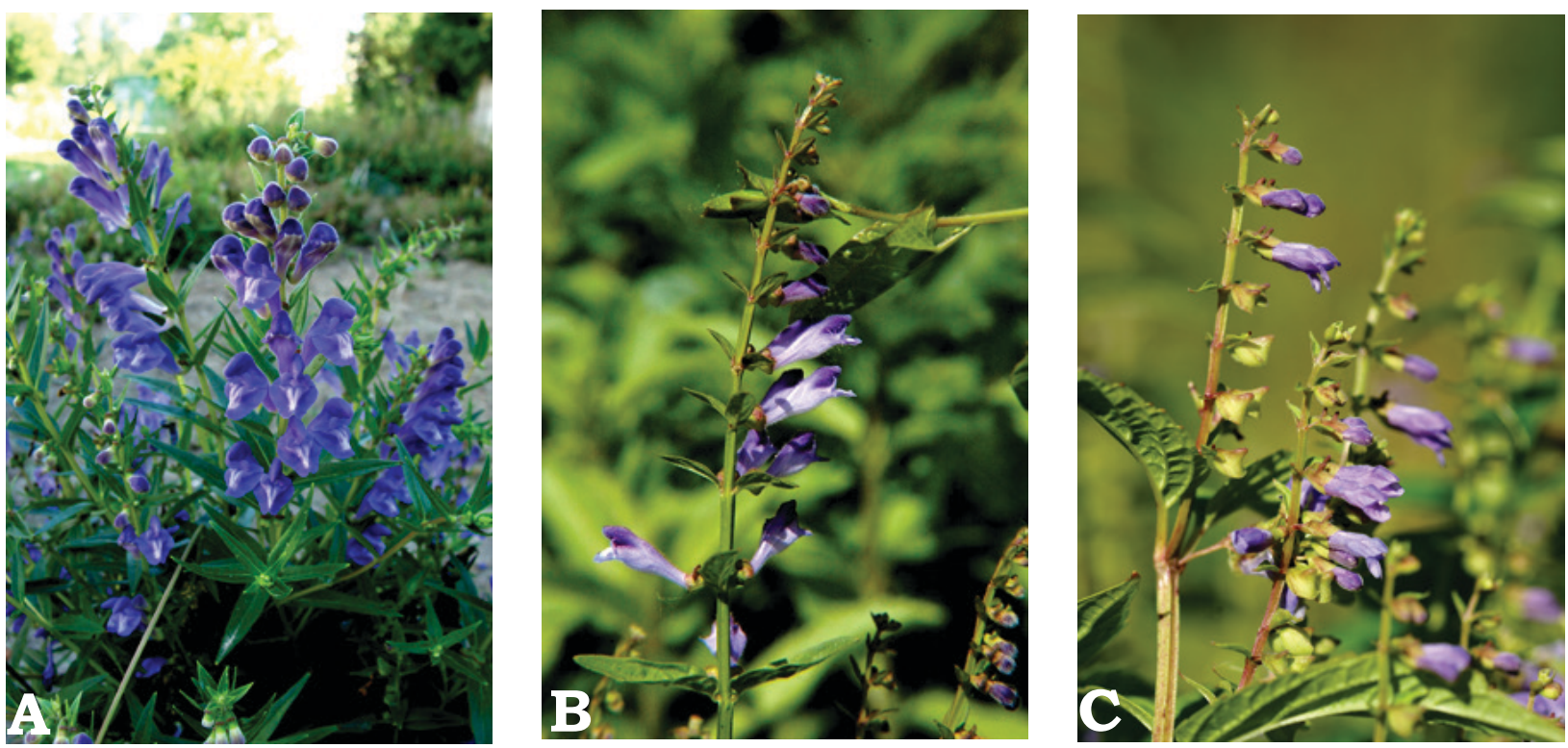

Ryc. 2. Pokrój morfologiczny części nadziemnych gatunków tarczyc.

A - S. baicalensis (Fot. G. Zgórka); B - S. barbata (Źródło: https://www.heilpflanzenkatalog.net//220-ban-zhi-lianscutellaria-barbata.html); C - S. lateriflora (Fot. R. Engstrand, http://creativecommons.org/licenses/by-sa/3.0).

chroniły neurony hipokampa przed śmiercia $\mathrm{w}$ procesie apoptozy oraz wspierały utrzymanie integralności bariery krew-mózg. Uważa się, że aktywność neuroprotekcyjna flawonów tarczycy bajkalskiej wynika nie tylko $z$ hamowania apoptozy $\mathrm{w}$ tkance nerwowej, ale także silnego działania ochronnego przed szkodliwym wpływem RFT, generowanych $\mathrm{w}$ dużych ilościach $\mathrm{w}$ stanach niedokrwienia mózgu (ZHAO i współaut. 2013, KONG i współaut. 2014, Li i współaut. 2016). Efekty neuroprotekcyjne zaobserwowano również w badaniach in vivo $\mathrm{z}$ wykorzystaniem modelu choroby Parkinsona u myszy. Zespół flawonoidów z ziela tarczycy bajkalskiej wpływał na poprawę wyników testów behawioralnych u zwierzat. Udokumentowano działanie ochronne na neurony dopaminergiczne, zlokalizowane $\mathrm{w}$ istocie czarnej mózgu oraz wskazano, że u podłoża aktywności neuroprotekcyjnej leży działanie przeciwwolnorodnikowe składników flawonoidowych ekstraktów (Li i współaut. 2016).

Wyciagi $z$ korzeni tarczycy bajkalskiej działają również cytoprotekcyjnie na komórki czynnościowe watroby, czyli hepatocyty. Jednym $z$ niekorzystnych procesów patofizjologicznych obserwowanych $\mathrm{w}$ obrębie tego organu jest jego zwłóknienie, które związane jest m.in. $z$ aktywacja komórek gwiaździstych (HSC) odpowiedzialnych za wydzielanie białek macierzy zewnątrzkomórkowej, w tym kolagenu typu 1 . Istotny wpływ na aktywacje HSC posiadaja cytokiny oraz RFT, odpowiedzialne za rozwój stresu oksydacyjnego, które współdziałaja dodatkowo z kinazami aktywowanymi mitogenami (MAPK), odpowiedzialnymi za rozwój procesów neoplastycznych (PlewKA i współaut. 2009). Składniki flawonowe tarczycy bajkalskiej wykazuja zdolność hamowania procesu zwłóknienia watroby poprzez zatrzymanie cyklu komórkowego aktywowanych komórek gwiaździstych w fazie $\mathrm{G} 2 / \mathrm{M}$, ograniczanie procesu apoptozy oraz aktywności MAPK (PAN i współaut. 2012). Również w przypadkach toksycznych uszkodzeń wątroby (np. w przewlekłej chorobie alkoholowej, wywoływanej u zwierzat doświadczalnych) podawanie wyciagów $\mathrm{z}$ korzeni tarczycy bajkalskiej chroniło hepatocyty przed rozwojem ostrego stanu zapalnego, $z$ następcza marskością, wskutek ograniczania stresu oksydacyjnego $\mathrm{w}$ siateczce śródplazmatycznej (DONG i współaut. 2016). Ochronne działanie składników flawonowych tarczycy bajkalskiej obejmuje także struktury komórkowe nerek. W badaniach in vivo, przeprowadzonych przez chińskich naukowców (FANG i współaut. 2015, 2016), długotrwałe podawanie szczurom, którym usunięto czesść nerek lub wywołano jednostronna niedrożność moczowodów, zespołu aglikonów flawonowych z korzeni tarczycy bajkalskiej hamowało proces zwłóknienia narządowego i zmniejszało dysfunkcję nefronów. Świadczy to o dużym potencjale terapeutycznym tych składników w łagodzeniu skutków przewlekłej niewydolności nerek.

Tarczyca bajkalska znana jest także $z$ silnych właściwości przeciwzapalnych, zwiazanych $\mathrm{Z}$ hamowaniem aktywności różnorodnych czynników rozwoju zapalenia, ta- 
kich jak: cyklooksygenazy 1 i 2 (COX-1 i 2), interleukiny 1 i 2 (IL-1 i 2), czynnik martwicy guza (TNF-a), tlenek azotu (NO) i inne, co wpływa na ograniczanie zmian degeneracyjnych w strukturze różnych tkanek $i$ narzadów. W badaniach in vivo, wodne ekstrakty $z$ korzeni tarczycy bajkalskiej hamowały rozwój indukowanych działaniem lipopolisacharydu zmian histopatologicznych w obrębie płuc (CHEN i współaut. 2017). Mechanizm przeciwzapalny leżał również u podstawy ograniczania procesów miażdżycowych w śródbłonku tętnic przez składniki flawonowe (głównie bajkalinę), zawarte w wodnych ekstraktach $z$ korzeni tego taksonu (KIM i współaut. 2015). Najnowsze badania in vitro, przeprowadzone przez amerykańskich naukowców (KHAN i współaut. 2017), dostarczyły dowodów na skuteczność wyciagów $z$ korzeni tarczycy bajkalskiej (bogatych w wogoninę), w terapii choroby zwyrodnieniowej stawów. Jako mechanizm działania tych preparatów, naukowcy wskazali zahamowanie procesów zapalnych i zmniejszenie stresu oksydacyjnego.

W ramach aktywności adaptogennej, udokumentowano także korzystny wpływ składników flawonowych tarczycy bajkalskiej w stanach nerwicowych i lękowych, powodowanych działaniem stresorów psychicznych. Aktywność tych związków porównuje się nawet do działania saponinowych pochodnych dammaranu, wystepujacych w korzeniach żeń-szenia. W badaniach behawioralnych na myszach i szczurach, wodne ekstrakty $z$ korzeni tarczycy bajkalskiej zwiększały odporność zwierząt na sytuacje stresowe, co przejawiało się spadkiem poziomu kortykosteronu w osoczu, jednego $z$ kluczowych hormonów steroidowych, uwalnianych w nadnerczach pod wpływem bodźców stresogennych (RYU i współaut. 2004).

\section{TARCZYCA BRODATA}

Obszarem rodzimego występowania tarczycy brodatej sa południowe Chiny, gdzie gatunek ten bytuje najczęściej w środowiskach o dużej zawartości wilgoci w glebie (podmokłe łąki, obrzeża stawów, potoków, itp.). Bylina ta osiaga jedynie połowę wysokości tarczycy bajkalskiej, dorastając do ok. $35 \mathrm{~cm}$. Blaszki liściowe o kształcie lancetowatym lub lekko trójkątnym charakteryzuja się niewielkim ząbkowaniem. Kwiaty, długości ok. $1 \mathrm{~cm}$, maja barwę purpurowo-niebieska, która u nasady korony przechodzi w kolor biały (Ryc. 2B). Ziele tarczycy brodatej wywodzi się również z TCM, gdzie znane jest pod nazwa „Ban-zhi-lian” (Hu 2005). Chińczycy wykorzystuja najczęściej tę roślinnę w leczeniu schorzeń nowotworowych, obrzę- ków różnego pochodzenia, stanów zapalnych jamy ustnej i gardła, jelit oraz układu moczowego. Ponadto, tarczyca brodata jest znanym remedium uśmierzającym ból i obrzęk tkanek spowodowany ukąszeniem węża (SHANG i współaut. 2010, WANG i współaut. 2012). Wśród lekarzy TCM dużą popularnością cieszy się stosowanie wyciagów $z$ tarczycy brodatej u pacjentów ze schorzeniami onkologicznymi. Ograniczeniem stosowania tego typu preparatów jest jedynie znacznie zaawansowany przebieg choroby nowotworowej, ponieważ mogłoby to spowodować dodatkowe osłabienie chorego, zmniejszenie apetytu i wystapienie zaburzeń żoładkowo-jelitowych. Poza schorzeniami nowotworowymi, specjaliści TCM wykorzystuja Ban-zhi-lian w leczeniu zarówno infekcji bakteryjnych, jak i toczących się w organizmie procesów zapalnych. $Z$ tego względu, ziele tarczycy brodatej znalazło m.in. zastosowanie $w$ terapii stanów zapalnych górnych dróg oddechowych o etiologii bakteryjnej, trądziku ropnego czy też przewlekłych zakażeń dróg moczowych. Z drugiej strony, Ban-zhi-lian stosuje się tak$\dot{z} \mathrm{e}$ w stanach zapalnych watroby (w tym o podłożu autoimmunologicznym), nerek czy wrzodziejącym zapaleniu okrężnicy (TAO i BALUNAS 2016). Najczęstsza forma leku, podawanego per os, sa wodne wyciagi (odwary), sporzadzane zwyczajowo $z 15$ do $60 \mathrm{~g}$ ziela tarczycy brodatej (Wu 2005).

Współczesne badania naukowe gatunku S. barbata koncentrują się wokół aktywności przeciwnowotworowej wyciagów $z$ ziela tego gatunku. Jednym $z$ odnotowywanych mechanizmów aktywności antyneoplastycznej jest inicjacja procesu apoptozy w szlaku wewnatrzpochodnym (mitochondrialnym). Szlak ten uruchamiany jest bezpośrednio poprzez kontakt (np. RFT) z zewnętrzna błona mitochondrium albo przez uszkodzenie chromatyny jądrowej, w wyniku czego dochodzi do zmiany przepuszczalności struktury błon mitochondrium. Białka $z$ rodziny baklin (Bax i Bad) uczestnicza w uwolnieniu cytochromu c do cytoplazmy, gdzie zachodzi kaskadowa aktywacja kaspazy-9 i kaspazy-3, uruchamiajacca fazę wykonawcza apoptozy (KONTUREK 2007). Składniki czynne ekstraktów $z$ ziela tarczycy brodatej, w badaniach in vitro hamowały proliferację różnych rodzajów komórek raka watroby, inicjujac proces apoptozy w szlaku wewnątrzpochodnym (DAI i współaut. 2008, GAO i współaut. 2014). Ograniczały także rozwój nowotworów i tworzenie metastaz, hamujac angiogenezę. Potwierdzono to m.in. w badaniach wyciagów $z$ ziela tarczycy brodatej $u$ myszy z wszczepionymi komórkami ludzkiego raka okrężnicy (WEI i współaut. 2012). Wyciagi $z$ tarczycy brodatej moga również 
wywierać efekt przeciwnowotworowy poprzez wpływ na cykl komórek nowotworowych. W badaniach na liniach komórkowych ludzkiej białaczki promielocytowej zaobserwowano zatrzymanie cyklu w fazie G1, co wiazało się ze zmniejszeniem w komórkach ilości specyficznych białek $z$ grupy cyklin oraz spadkiem aktywności cyklinozależnych kinaz (KIM i współaut. 2007). Bezielle (BZL101), czyli wodny ekstrakt otrzymany $z$ ziela tarczycy brodatej, przeszedł już pozytywnie pierwszy etap badań klinicznych, jako lek planowany do stosowania $\mathrm{u}$ kobiet $\mathrm{w}$ rozsianym raku piersi (RUGO i współaut. 2007, PEREZ i współaut. 2010). Niezwykle ważnym faktem jest, że Bezielle działa wybiórczo na komórki raka piersi, jednocześnie nie wykazując istotnej toksyczności wobec normalnych komórek nabłonkowych sutka (FONG i współaut. 2008). Jako adaptogen, tarczyca brodata odznacza się także znaczacca aktywnościa cytoprotekcyjną. Jednym $z$ jej przejawów jest działanie ochronne na OUN, udokumentowane w badaniach na zwierzetach. Dowiedziono m.in., że ekstrakty etanolowe otrzymane $z$ ziela tego gatunku zmniejszaja zaburzenia funkcji poznawczych mózgu powstałych w przebiegu niedokrwienia mózgu (ZHANG i LI 2016, Wu i współaut. 2016). Moga także stanowić obiecujacy nowy środek w leczeniu choroby Alzheimera. W badaniach na szczurach, u których sztucznie wygenerowano model choroby Alzheimera, zespół flawonoidów $z$ ziela tarczycy brodatej ograniczał bowiem powstawanie uszkodzeń neuronów oraz zmniejszał stopień nasilenia zaburzeń pamięci (WU i współaut. 2016). W badania in vivo udokumentowano także aktywność hepatoprotekcyjna preparatów $z$ ziela tarczycy brodatej. Efekt ochronny na tkanki watroby potwierdzono dla różnych hepatotoksyn (LIN i współaut. 1997).

\section{TARCZYCA BOCZNOKWIATOWA}

Tarczyca bocznokwiatowa jest bylina, która występuje naturalnie w Ameryce Północnej, zasiedlając szczególnie chętnie podmokłe tereny od Alaski po Florydę oraz od Kolumbii Brytyjskiej po Quebec. Gatunek ten dorasta do $80 \mathrm{~cm}$ wysokości. Duże liście, osiagajacce nawet $8 \mathrm{~cm}$ długości, sa owalne, czasem owalno-lancetowate, a brzeg blaszki liściowej charakteryzuje się obecnościa zaokraglonych zą̧ków. Pomimo że wśród omawianych gatunków tarczyca bocznokwiatowa osiaga największe rozmiary, jeśli chodzi o wysokość głównego pędu, to ma najmniejsze kwiaty (6-8 mm długości), które barwią się na fioletowo-niebiesko (Ryc. 2C).

W etnomedycynie obu Ameryk gatunek ten wykorzystywano w leczeniu różnorod- nych zaburzeń psychicznych, m.in. stanów lękowych, napadów histerii, fobii, depresji oraz problemów $z$ zasypianiem. Ponadto, tarczyca bocznokwiatowa stosowana była przez kobiety $z$ plemienia Czirokezów jako środek pobudzający menstruację oraz $\mathrm{w}$ celu ułatwienia wydalenia łożyska po porodzie. Niektóre plemiona nadal stosuja wyciagi $z$ tej rośliny podczas ceremonii wprowadzenia dziewczynek w dorosłość (BROCK i współaut. 2012). Kanadyjczycy nabywaja czesto w sklepach ze zdrowa żywnościa rozdrobnione ziele tarczycy bocznokwiatowej. Stosuja je w celu sporządzenia naparów albo, w połaczeniu $z$ korzeniem kozłka i zielem męczennicy, $\mathrm{w}$ postaci tabletek, majacych działanie relaksacyjne i ułatwiajacych zasypianie (SHANG i współaut. 2010). Zastosowania lecznicze tarczycy bocznokwiatowej, znane $z$ etnomedycyny, potwierdzaja wyniki prowadzonych obecnie badań przedklinicznych i klinicznych. Uważa się, że właściwości adaptogenne ziela tego gatunku szczególnie przejawiaja się w stabilizującym wpływie jego składników na funkcje OUN, co wyraża się w ograniczaniu stanów napięcia nerwowego oraz wspomaganiu mechanizmów adaptacji organizmu do warunków stresowych. Jak udowodniono podczas badań behawioralnych na zwierzętach, ekstrakty wodne $z$ ziela tarczycy bocznokwiatowej zwiększały odporność psychofizyczna zwierzat na działanie różnorodnych stresorów (AWAD 2003). W 2012 r. brytyjscy naukowcy opublikowali wyniki badania pilotażowego, przeprowadzonego w Wielkiej Brytanii i Irlandii, dotyczacego stosowania tarczycy bocznokwiatowej u zdrowych ochotników. Wykazano, że S. lateriflora jest ceniona roślina stosowana $\mathrm{w}$ celu zmniejszenia stanów lękowych i stresu (BROCK i współaut. 2012). W kolejnych badaniach, przeprowadzonych przez tych samych autorów na ochotnikach, porównywano efekt działania ekstraktów $z$ ziela tarczycy bocznokwiatowej i placebo $\mathrm{w}$ okresie 14 dni. Wykazano, że badane wyciagi odznaczały się działaniem przeciwlękowym i poprawiajacym nastrój, jednocześnie nie powodując spadku energii i zaburzeń funkcji poznawczych. Co istotne, w trakcie stosowania preparatów $z$ tarczycy bocznokwiatowej nie zaobserwowano efektów toksycznych ani działań niepożądanych (BROCK i współaut. 2014). Mechanizm działania przeciwlękowego tarczycy bocznokwiatowej naukowcy opieraja na powinowactwie składników flawonowych (bajkaliny, bajkaleiny i wogoniny) do receptora GABA $\mathrm{w}$ miejscu wiazania znanych syntetycznych anksjolityków $\mathrm{z}$ grupy benzodiazepin (BROCK i współaut. 2012). Dodatkowo, w innych badaniach ustalono, że składniki aktywne wodnych i wodno-alkoholowych ekstraktów 
z ziela tarczycy bocznokwiatowej wykazuja zdolność wiązania $z$ receptorami serotoninergicznymi (5-HT $)$, co może zostać wykorzystane w terapii zburzeń snu, depresji, bólów migrenowych oraz zaburzeń pamięci (GAFNER i współaut. 2003).

\section{WYKORZYSTANIE EKSTRAKTÓW Z TARCZYC W POLSKIM LECZNICTWIE}

W Polsce, w lecznictwie oficynalnym, wykorzystuje się obecnie aktywność przeciwzapalna i przeciwdrobnoustrojowa standaryzowanych wyciagów $z$ korzeni tarczycy bajkalskiej w preparatach stosowanych zewnętrznie. Wiodącym wytwórca $w$ tej dziedzinie sa Wrocławskie Zakłady Zielarskie „Herbapol” SA. Jednym $z$ najbardziej popularnych produktów leczniczych jest żel dentystyczny Baikadent ${ }^{\circledR}$, wykorzystywany $\mathrm{w}$ terapii stanów zapalnych i mikrourazów błony śluzowej w obrębie jamy ustnej, jak również schorzeniach przyzębia. W ofercie producenta znajdziemy również płyn do płukania jamy ustnej o tej samej nazwie, którego wskazania uzupełniono o leczenie schorzeń o podłożu grzybiczym. Maść Baikaderm ${ }^{\circledR}$ polecana jest $z$ kolei w chorobach powłok skórnych o etiologii zapalnej lub drobnoustrojowej. Wyciagi z korzenia tarczycy bajkalskiej znalazły także zastosowanie w preparatach kosmetycznych do pielegnacji okolic intymnych, takich jak: żel Baifem $\mathrm{K}^{\circledR}$ czy pianka Baifem ${ }^{\circledR}$, zalecanym kobietom do codziennej higieny okolic intymnych, a także łagodzenia podrażnienia i wspomagania procesów regeneracji błony śluzowej w tym obszarze. W polskich sklepach zielarskich można także nabyć suszony i rozdrobniony korzeń tarczycy bajkalskiej, $z$ którego sporządzone odwary zaleca się przyjmować doustnie zwłaszcza w schorzeniach wątroby o podłożu zapalnym oraz stanach napięcia nerwowego i zaburzeniach snu.

\section{PODSUMOWANIE}

Składniki polifenolowe (głównie flawonowe) trzech omawianych gatunków tarczyc w różnorodny sposób przejawiajac aktywność adaptogenną. Wyraża się ona w ochronie tkanek i narządów przed uszkodzeniami, w czym kluczowa rolę odgrywaja mechanizmy antyoksydacyjne i antywolnorodnikowe, promujace przede wszystkim silne działanie przeciwzapalne tych składników. Ze względu na obserwowany w dzisiejszych czasach znaczący wzrost liczby schorzeń biodegeneracyjnych, na szczególną uwage zasługuje aktywność neuro- i hepatoprotekcyjna wyciagów z ziela i korzeni tarczycy bajkalskiej, ograniczanie procesów neoplastycznych przez składniki czynne wyciagów $z$ ziela tarczycy brodatej, jak również normalizujący wpływ ekstraktów z ziela tarczycy bocznokwiatowej na funkcję OUN, związany $z$ łagodzeniem zaburzeń psychicznych i neurowegetatywnych, powstałych wskutek działania różnorodnych stresorów środowiskowych. Na podkreślenie zasługuje także fakt, że wyciągi $z$ omawianych gatunków tarczyc charakteryzuje bardzo niska toksyczność w stosunku do zdrowych komórek organizmu, co czyni je atrakcyjna alternatywa zwłaszcza dla starszych pacjentów $z$ zaburzonymi mechanizmami autoadaptacji. $Z$ tego względu, wodne wyciagi $z$ korzeni tarczycy bajkalskiej czy ziela tarczycy bocznokwiatowej i brodatej zaleca się stosować wspomagająco w stanach zapalnych wątroby, będacych następstwem przewlekłych uszkodzeń hepatocytów, a także niektórych schorzeniach neurodegeneracyjnych (choroba Alzheimera) oraz w przypadkach obniżonej tolerancji na stres psychiczny (stany lękowe, nerwice wegetatywne, zaburzenia snu).

\section{Streszczenie}

Roślinne adaptogeny wykazuja wiele efektów farmakologicznych w organizme ludzkim, charakteryzując się jednocześnie dużym bezpieczeństwem stosowania. Liczne substancje roślinne, obdarzone właściwościami adaptogennymi, wywodza się z Tradycyjnej Medycyny Chińskiej (TCM). Część $z$ nich znalazła również zastosowanie w konwencjonalnej medycynie zachodniej. Celem niniejszej publikacji jest przybliżenie potencjału terapeutycznego trzech gatunków roślin $z$ rodzaju Scutellaria L. (tarczyca), charakteryzujących się aktywnością adaptogenną. Tarczyce: bajkalska (Scutellaria baicalensis Georgi.) oraz brodata (Scutellaria barbata D.Don.) to dwa gatunki azjatyckie wykorzystywane w TCM, natomiast tarczyca bocznokwiatowa (Scutellaria lateriflora L.) jest taksonem rodzimym flory Ameryki Północnej, stosowanym pierwotnie w medycynie ludowej Indian. Głównymi składnikami tarczyc, którym przypisuje się właściwości adaptogenne sa składniki polifenolowe $z$ grupy flawonów (głównie: bajkaleina, bajkalina, wogonina). Wyciagi $z$ tarczyc, bogate $\mathrm{w}$ te zwiazki, stanowia środki lecznicze o silnym działaniu przeciwzapalnym, wykazujace szeroka aktywność antybiodegeneracyjna (neuro- hepato- i kardioprotekcyjna) oraz przeciwnowotworowa. Ponadto, jako adaptogeny, flawony tarczyc wykazuja normalizujący wpływ na OUN, łagodzac dolegliwości natury psychicznej, w tym reakcje lękowe, stany napięcia nerwowego czy zaburzenia snu.

\section{LITERATURA}

Awad R., Arnason J. T., Trudeau V., Bergeron C., Budzinski J. W., Foster B. C., Merali Z., 2003. Phytochemical and biological analysis of skullcap (Scutellaria lateriflora L.): a medicinal plant with anxiolytic properties. Phytomedicine 10, 640-649.

Bown D., 1999. Wielka encyklopedia ziół. Muza S.A., Warszawa.

Brock C., WhITEHOUSE J., TEWFIK I., TOWELl T., 2012. The use of Scutellaria lateriflora: a pilot survey amongst herbal medicine practitioners. J. Herb. Med. 2, 34-41. 
Brock C., Whitehouse J., TEWFIK I., TOWELL T., 2014. American Skullcap (Scutellaria lateriflora): A randomised, double $\square$ blind placebo $\square$ controlled crossover study of its effects on mood in healthy volunteers. Phytother. Res. 28, 692-698.

Chen J. J., Huang C. C., Chang H. Y., Li P. Y., Liang Y. C., Deng J. S., Huang S. S., Huang G. J., 2017. Scutellaria baicalensis ameliorates acute lung injury by suppressing inflammation in vitro and in vivo. Am. J. Chin. Med. 45, 137-157.

DAI Z. J., WANG X. J., LI Z. F., Ji Z. Z., REN H. T., TANG W., LIU X. X., Kang H. F., GUAN H. T., SONG L. Q., 2008. Scutellaria barbate extract induces apoptosis of hepatoma H22 cells via the mitochondrial pathway involving caspase-3. World J. Gastroenterol. 14, 73217328.

Dong Q., Chu F., Wu C., Huo Q., Gan H., Li X., LIU H., 2016. Scutellaria baicalensis Georgi extract protects against alcohol-induced acute liver injury in mice and affects the mechanism of ER stress. Mol. Med. Rep. 13, 3052-3062.

FANG J., WANG W., SUN S., WANG Y., Li Q., LU X., HAO Z., ZHANG Y., 2015. A urine metabonomics study of chronic renal failure and intervention effects of total aglycone extracts of Scutellaria baicalensis in 5/6 nephrectomy rats. RSC Adv. 5, 75612-75621.

FANG J., WANG W., SUN S., WANG Y., LI Q., LU X., QIU M., ZHANG Y., 2016. Metabolomics study of renal fibrosis and intervention effects of total aglycone extracts of Scutellaria baicalensis in unilateral ureteral obstruction rats. J. Ethnopharmacol. 192, 20-29.

Fong S., Shoemaker M., CadaOAS J., LO A., LiaO W., TAGLiaferri M., COHEN I., SHTIVElman E., 2008. Molecular mechanisms underlying selective cytotoxic activity of BZL101, an extract of Scutellaria barbata, towards breast cancer cells. Cancer Biol. Ther. 7, 577-86.

Gafner S., Bergeron C., BATCHA L. L., REICH J., ARnason J. T., BurdetTe J. E., Pezzuto J. M., ANGERHOFER C. K., 2003. Inhibition of [3H]-LSD Binding to 5-HT7 Receptors by Flavonoids from Scutellaria lateriflora. J. Nat. Prod. $66,535-537$

GaO J., Lu W. F., Dai Z. J., Lin S., ZhaO Y., LI S., ZHAO N. N., WANG X. J., KANG H. F., MA X. B., ZHANG W. G., 2014. Induction of apoptosis by total flavonoids from Scutellaria barbata D. Don in human hepatocarcinoma $\mathrm{MH}$ CC97-H cells via the mitochondrial pathway. Tumour Biol. 35, 2549-2559

HU S. Y, 2005. Food Plants of China. The Chinese University Press, Hong Kong, 654-655.

KHAN N. M., HASEEB A., ANSARI M. Y., HAQQI T. M., 2017. A wogonin-rich-fraction of Scutellaria baicalensis root extract exerts chondroprotective effects by suppressing IL-1ß-induced activation of $A P-1$ in human OA chondrocytes. Sci. Rep. 7, 43789.

KIM E. K., KwON K. B., HAN M. J., SONG M. Y., LEE J. H., Ko Y. S., SHIN B. C., YU J., LEE Y. R., RYU D. G., PARK J. W., PARK B. H., 2007. Induction of G1 arrest and apoptosis by Scutellaria barbata in the human promyelocytic leukemia HL-60 cell line. Int. J. Mol. Med. 20, 123-128.

KIM O. S., SEO C. S., KIM Y., ShIN H. K., HA H., 2015. Extracts of Scutellariae Radix inhibit low-density lipoprotein oxidation and the lipopolysaccharide-induced macrophage inflamma tory response. Mol. Med. Rep. 12, 1335-1341.
Kong X., Kong W., MiaO G., ZhaO S., Chen M., ZHENG X., BAI J., 2014. Pretreatment with Scutellaria baicalensis stem-leaf total flavonoid protects against cerebral ischemia/reperfusion injury in hippocampal neurons. Neural Regen. Res. 9, 2066-2073.

KONTUREK S., 2007. Fizjologia człowieka: podrecznik dla studentów medycyny. Elsevier Urban \& Partner. Wrocław.

LEE N. H., Son C. G., 2011. Systematic review of randomized controlled trials evaluating the efficacy and safety of ginseng. J. Acupunct. Meridian Stud. 4, 85-97.

Li X. L., XU X. F., BU Q. X., Jin W. R., SUN Q. R., FENG D. P., ZHANG Q. J., WANG L. X., 2016. Effect of total flavonoids from Scutellaria baicalensis on dopaminergic neurons in the substantia nigra. Biomed. Rep. 5, 213-216.

LIN C. C., SHIEH D. E., YEN M. H., 1997. Hepatoprotective effect of the fractions of Ban-zhi-lian on experimental liver injuries in rats. J. Ethnopharmacol. 56, 193-200.

OBIDOSKA G., SADOWSKA A., 2004. Rośliny o działaniu adaptogennym. Biuletyn Instytutu Hodowli i Aklimatyzacji Roślin 233, 163-171.

PAN T. L., WANG P. W., LEU Y. L., WU T. H., Wu T. S., 2012. Inhibitory effects of Scutellaria baicalensis extract on hepatic stellate cells through inducing G2/M cell cycle arrest and activating ERK-dependent apoptosis via Bax and caspase pathway. J. Ethnopharmacol. 139, 829-837.

PANOSSIAN A., WIKMAN G., 2009. Evidence-based efficacy of adaptogens in fatigue, and molecular mechanisms related to their stress-protective activity. Curr. Clin. Pharmacol. 4, 198219.

PANOSSIAN A., WikMAN G., WAGNER H., 1999. Plant adaptogens III. Earlier and more recent aspects and concepts on their mode of action. Phytomedicine 6, 287-300.

PAWŁOWSKI B., 1967. Flora polska. Rośliny naczy niowe Polski i ziem ościennych. Tom XI. PWN, Warszawa-Kraków.

PEREZ A. T., ARUN B., TRIPATHY D., TAgliaferRI M. A., SHAW H. S., KIMMICK G. G., COHEN I., Shtivelman E., CAYGill K. A., Grady D., SCHACTMAN M., SHAPIRO C. L., 2010. A phase $1 B$ dose escalation trial of Scutellaria barbata (BZL101) for patients with metastatic breast cancer. Breast Cancer Res. Treat. 120, 111118.

PlewKa K., SzUSTER-Ciesielska A., Kandefer-SZERSZEŃ M., 2009. Rola komórek gwiaździstych $w$ procesie alkoholowego włóknienia watroby. Postępy Hig. Med. Dośw. 63, 303-317.

Rugo H., Shtivelman E., Perez A., Vogel C., Franco S., Tan ChiU E., MElisko M., TagliAFERri M., COHEN I., SHOEMAKER M., TRAN Z., TRIPATHY D., 2007. Phase I trial and antitumor effects of BZL1O1 for patients with advanced breast cancer. Breast Cancer Res. Treat. 105, 17-28.

RUTKOWSKI L., 1998. Klucz do oznaczania roślin naczyniowych Polski niżowej. PWN, Warszawa.

Ryu J. H., TAN-LeE B. S., Jung J. W., AhN N. Y., LEE S. J., Yu G. Y., HAN S. H., LEE J. H., LEe G. S., CheOng J. H., 2004. Anti-stress Effect of Scutellatia baicalensis in SD Rats and ICR Mice. J. Appl. Pharmacol. 12, 34-42.

Shang X., HE X., He X., Li M., Zhang R., FAN P., ZHANG Q., JIA Z., 2010. The genus Scutellaria an ethnopharmacological and phytochemical review. J. Ethnopharmacol. 128, 279-313. 
SZAFER W., KULCZYŃSKI S., PAWŁOWSKI B., 1988. Rośliny polskie, cz. I i II. PWN, Warszawa.

TANG J. L., LIU B. Y., MA K. W., 2008. Traditional Chinese medicine. Lancet 372, 1938-1940.

TAO G., Balunas M. J., 2016. Current therapeutic role and medicinal potential of Scutellaria barbata in Traditional Chinese Medicine and Western research. J. Ethnopharmacol. 182, $170-180$

The Plant List, 2013. Version 1.1. Published on the Internet; http://www.theplantlist.org/.

WANG T., WANG S., XIAO D., 2012. A review of phytochemistry and antitumor activity of a valuable medicinal species: Scutellaria barbata. J. Med. Plant. Res. 6, 4259-4275.

Wei L., LiN J., XU W., CAI Q., Shen A., Hong Z., PENG J., 2012. Scutellaria barbata D. Don inhibits tumor angiogenesis via suppression of hedgehog pathway in a mouse model of colorectal cancer. Int. J. Mol. Sci. 13, 94199430.
Wu J. N., 2005. An Illustrated Chinese Materia Medica. Oxford University Press, New York, 460-461.

Wu X. G., Wang S. S., MiaO H., Cheng J. J., ZHANG S. F., SHANG Y. Z., 2016. Scutellaria barbata flavonoids alleviate memory deficits and neuronal injuries induced by composited $A \beta$ in rats. Behav. Brain Funct. 12, 33.

ZHANG Y., LI Y., 2016. Effect of total flavonoids of Scutellaria barbata on cognitive function and nogo-A expression in the hippocampus in cerebral ischemia model in gerbils. Pak. J. Pharm. Sci. 29, 2373-2376.

ZHAO Q., CHEN X. Y., MARTIN C., 2016. Scutellaria baicalensis, the golden herb from the garden of Chinese medicinal plants. Sci. Bull. 61, 1391-1398.

Zhao S., Kong W., Zhang S., Chen M., Zheng X., KONG X., 2013. Pretreatment with Scutellaria baicalensis stem-leaf total flavonoid prevents cerebral ischemia-reperfusion injury. Neural Regen. Res. 8, 3183-3192.

KOSMOS Vol. 67, 3, 625-633, 2018

\section{BENITA HRYĆ, GRAŻYNA ZGÓRKA}

Chair and Department of Pharmacognosy with Medicinal Plant Unit, Medical University of Lublin, 1 Chodźki Str., $20-093$ Lublin, e-mail: benita.hryc@gmail.com; gzgorka@pharmacognosy.org

\section{SKULLCAPS - PLANT ADAPTOGENS FROM VARIOUS CONTINENTS}

\section{Summary}

Plant adaptogens exert many pharmacological effects on human body with concomitant little toxicity. Numerous plant substances with adaptogenic properties are derived from Traditional Chinese Medicine (TCM). Some of them have been also used in Western medicine. The aim of this paper is to describe therapeutic potential of three Scutellaria L. (skullcap) species, which possess adaptogenic activity. Baikal and barbed skullcaps, which are native for Asia, were used in TCM, whereas mad dog skullcap is native to North America, where it was used by American Indians. The main skullcap compounds showing adaptogenic properties are flavones (mainly: baicalein, baicalin, wogonin) classified as polyphenols. Extracts obtained from skullcaps, rich in those compounds, are strong antiphlogistic therapeutic agents showing wide antibiodegenerative (neuro-, hepato- and cardioprotective) and antineoplastic activities. Furthermore, as adaptogens, skullcap flavones reveal normalizing effects on central nervous system by alleviating common mental ailments, like anxiety, nervous tension or sleeping disorders.

Key words: antibiodegenerative activity, plant adaptogens, Scutellaria L. (skullcap) genus 